В. В. Кондрашин, О. А. Сухова

\title{
Феномен вредительства
}

в социально-политическом контексте

и современном дискурсе

гуманитарного знания ${ }^{1}$

\section{Кондрашин \\ Виктор \\ Викторович, доктор исторических наук, профрессор, Пензенский государственный университет (Пенза, Россия)}

Сухова

Ольга

Александровна, доктор исторических наук, профрессор, декан историкофилологического факультета, Пензенский государственный университет (Пенза, Россия)
Изучение советской истории представляется сегодня делом сложным и неблагодарным по ряду причин. Прежде всего, следует учитывать длительный период идеологических спекуляций на волне требований тотального отрицания опыта советской идентичности, истребления «совковости», а вместе с этим исторической памяти трех поколений и, следовательно, возможности самопознания, рефлексии. Так, в 2011 г. Советом по гражданскому обществу и правам человека был инициирован проект общенациональной программы «Об увековечении памяти жертв тоталитарного режима и о национальном примирении», вызвавший ожесточенную дискуссию в научном сообществе. Результаты экспертного опроса по программе «детоталитаризации общественного сознания» были впоследствии опубликованы на страницах «Журнала российских и восточноевропейских исторических исследований»². Главной целью программы было заявлено ни много ни мало «окончание гражданской войны, развязанной в 1917 г.»³. Тиражирование подобных клишированных стереотипов, запущенное в конце 1980-х гг., сохраняет значение и по сей день, что препятствует формированию объективной картины советской истории. В одной из своих работ известный американский историк Моше Левин 
подверг критике тех исследователей, которые пытаются «волюнтаристически» «расширить границы» сталинизма, относя его возникновение к 1917 г. и продлевая агонию до момента распада СССР 4 . По мнению ученого, искажение исторической действительности в этом случае происходит по двум причинам: «Первая ошибка состоит в том, что исследование Советского Союза чаще всего подменяют антикоммунизмом. Вторая является следствием первой и состоит в сталинизации всего советского феномена, словно это был один гигантский ГУЛАГ от начала и до конца. Однако антикоммунизм (равно как и все его ответвления) не может быть основой осмысления советской истории» 5 .

Гораздо более продуктивный подход - констатация чрезмерной репрессивности сталинского режима на начальной стадии его становления как отражения психологической реакции традиционного общества, оказавшегося в горниле стремительной модернизации. В исследованиях последних лет в общем дискурсе проблемы сталинских репрессий появилось понимание того факта, что в самом процессе становления гражданского общества заложено мощное репрессивное начало (как стихийное, так и государственно-организованное насилие), необходимое для смены социокультурных ориентиров ${ }^{6}$. Впрочем, еще в конце $1920-x-$ в 1940-е гг. Х. Ортега-и-Гассет, а вслед за ним К. Ясперс возвестили о превращении масс в решающую силу истории. В построениях Ясперса крестьянство выступает неисторической субстанцией населения: «Сознание людей, даже если их ждала голодная смерть, оставалось сравнительно защищенным внутри неизменяющихся структур. Люди терпели, покорялись и жили во всеозаряющей религиозной вере ${ }^{7}$. Растущее неверие обернулось нигилизмом, на благодатной почве которого выросла идеология. «Распад традиционных ценностей обнаруживается только в том, - отмечает далее К. Ясперс, - что это разоблачающее мышление становится господствующим. Эпоха создает теорию того, что она совершает. Однако вскоре сама эта теория превращается в средство усиления зла, с которым она борется»8. Естественным результатом утраты прежних жизненных устремлений становится бегство от пустоты отрицания, от недовольства собой в поиск и наказание виновных: «В испорченном пропагандистской софистикой языке в конце концов вообще перестает быть понятным значение слов. Речь превращается в хаос неопределенностей»9.

Вместе с тем сложности выявления сущности советской идентичности обусловлены последствиями эпистемологического кризиса, охватившего социально-гуманитарные науки и спровоцировавшего пересмотр роли исторического источника и выдвижение на первый план внеисточникового исторического знания ${ }^{10}$.

В процессе изучения истории советского общества недоверие к историческому источнику усиливается многократно вследствие идеологизированности информации или ее намеренного искажения, что чрезвычайно затрудняет возможности критики предметной и содержательной стороны, определение подлинности и достоверности свидетельств, выявление и разделение истинных и ложных смыслов. По мнению О.В. Боровковой, в исследованиях последнего времени все более укрепляется суждение о невозможности познания прошлого в его подлинном смысле («как оно было»), что выступает серьезной угрозой для дефиниции предметного ядра исторической науки. Возможность преодоления 
столь явного противоречия видится в привлечении внеисторического знания, т.е. допущении по меньшей мере равенства источника и историка, владеющего определенным интеллектуальным и методическим инструментарием для совершения герменевтического прыжка ${ }^{11}$. На наш взгляд, познавательная ценность подобного видения проблемы очевидна: речь идет о предзнании, основанном на метадисциплинарном изучении специфики социально-политической конъюнктуры, исторического сознания, ментальности, социальных представлений, на личном опыте переживания событий настоящего и экстраполяции рефлексии на повседневные практики в исторической ретроспективе и применении всей совокупности методов критического анализа исторических источников (прежде всего герменевтики, извлечения явных и скрытых смыслов, интерпретации родовых знаков эпохи; дискурса, позволяющего представить текст как способ коммуникативного обмена информацией; контент-анализа, ответственного за корреляцию ментальной, идеологической и политической знаковых систем, и т. д.). И хотя такое установление контакта с прошлым, по меткому замечанию А. Я. Гуревича, влечет за собой «создание» и исторического источника, и исторических фактов, новый социально-культурный контекст, ориентирующий на реконструкцию всего многообразия знаковых систем, расширение границ исторического исследования до пределов «тотальности», не только реабилитирует обыденное сознание (в том числе заблуждения, суеверия и пр.) в качестве фактора социальной динамики, но и способствует выходу исторической науки на новый методологический уровень ${ }^{12}$.

Последовательными сторонниками такого переворота в интерпретации истории советского общества являются А. Я. Лившин и И. Б. Орлов, избравшие предметом исследовательской практики системные взаимоотношения личности, общества и власти, представленные в текстах различного рода обращений населения. Анализируя письма во власть, авторы приходят к выводу о мозаичности и многокомпонентности массового сознания в постреволюционную эпоху, «об уникальном сочетании в массовом менталитете прагматизма и коллективного бессознательного, этатизма и антигосударственных, анархистских устремлений»13.

Столь пространный экскурс в методологические и источниковедческие аспекты проблемы не случаен. Идеологема «вредительство» прочно вписана в исторический контекст производственной повседневности советской истории 1920-х - 1930-х гг. и во многих отношениях является родовым для советского проекта феноменом. Термин, вероятно, восходит к милитаристской практике политических реалий в период Гражданской войны и прочно соседствует с лексическими значениями всевозможных «фронтов», «борьбы», «осажденной крепости» и т.д. Однако определить время возникновения этой знаковой системы, равно как и роль пропагандистских институтов в ее создании, весьма затруднительно. По мнению И.Б. Арнаутова, образ вредителя был преимущественно вписан в общий контекст открытых судебных процессов второй половины 1930-х гг. В периодической печати кампания по борьбе с вредительством стартовала с ноября 1935 г. в рамках пропаганды стахановского движения и, соответственно, появления сопротивления последнему ${ }^{14}$.

Однако логика развития социально-политической конъюнктуры в первые постреволюционные десятилетия позволяет отнести возникновение 
правоприменения новой идеологемы к более раннему времени. Как известно, Уголовный кодекс РСФСР 1926 г. не квалифицировал вредительство в качестве самостоятельного вида преступлений, хотя сам термин активно использовался в тексте при характеристике мер социальной защиты или конкретизации ряда преступлений ${ }^{15}$.

Уникальные свидетельства, позволяющие реконструировать путь рождения понятия и его масштабы и значение в системе социально-политической коммуникации, представлены в работе О.Б. Мозохина ${ }^{16}$. В качестве приложений к монографии автор опубликовал статистические сведения о деятельности органов ВЧК - ОГПУ - НКВД - МГБ, диверсифицированные в фонде 8-ос Центрального архива ФСБ РФ. Несмотря на объективные погрешности по единообразию изложения материалов (вследствие постоянного изменения отчетности), автору удалось выявить уникальные данные, в том числе по статистике форм и видов социального сопротивления политике революционных властей в период с 1918 по 1953 г. ${ }^{17}$

Можно не доверять представленным статистическим данным, но значительно сложнее усомниться в намеренном искажении самих формулировок категорий преступлений. Как раз это и позволяет осуществить подлинную реконструкцию определенной знаковой системы. Критерием объективности полученных оценок выступит посылка о фиксации в лексических значениях непосредственной и повседневной политической практики, а следовательно, и исторического контекста деятельности властных структур. Итак, указание на чуждость определенных социальных элементов, введение в формы отчетности «знака», соотносимого с искомым понятием («социально вредный элемент»), относится к 1923 г. Примечательна и положительная динамика роста подобного рода преступлений: наблюдается буквально десятикратное увеличение показателей к 1927 г. ${ }^{18}$, хотя пока речь идет в основном о мелких преступлениях и преступлениях против общественного порядка и личности. Государственная безопасность здесь напрямую не затрагивается (хулиганство, изготовление, хранение и сбыт самогона, одурманивающих веществ, кража, принуждение к проституции, сводничество и пр.).

Отдельной строкой, самостоятельным видом преступлений «экономическая контрреволюция и вредительство» впервые фиксируется в отчетности 1929 г. При этом строка «социально вредный и опасный элемент» уже отнесена к разряду особо опасных преступлений (рост числа преступлений по сравнению с 1927 г. составил 3,7 раза - с 8707 до 40691$)^{19}$. Динамика масштабов внесудебной деятельности органов госбезопасности по пресечению вредительства на протяжении 1930-х гг. представлена следующими данными: 2846 преступлений по данным 1929 г.; 7275 случаев вредительства за 1930 г.; 17841 - в 1931 г.; затем наблюдается некоторое снижение показателя до 2791 случая вредительства в колхозах и совхозах, но при этом «сельская контрреволюция» дает 83602 случая за 1932 г.; 38692 - в 1933 г.; 6320 - в 1935 г.; 67701 - в 1937 г.; 44564 - в 1938 г.; далее наблюдается резкое снижение показателя до 1445 случаев - в 1939 г. ${ }^{20}$ Важно подчеркнуть, что противодействие стахановскому движению было выделено самостоятельной строкой в отчетности только в 1936 г. (вредительство - 2269 случаев; противодействие стахановскому движению - 1149) ${ }^{21}$. До 1945 г. к вредительству официальная статистика относила преступления по п. 7 ст. 58 УК (подрыв 
государственной промышленности, транспорта, торговли и т.д., совершаемый в интересах бывших собственников или заинтересованных капиталистических организаций; мера социальной защиты - расстрел), а также по п. 14 ст. 58 УК («контрреволюционный саботаж, т. е. сознательное неисполнение кем-либо определенных обязанностей или умышлено небрежное их исполнение со специальной целью ослабления власти правительства и деятельности государственного аппарата»; мера социальной защиты - лишение свободы сроком не менее одного года с конфискацией всего или части имущества, а при отягчающих обстоятельствах - расстрел). В дальнейшем саботаж был выделен в отдельный показатель статистики. Следует отметить сохранение подобной статистики и в 1953 г.; впрочем, общее количество преступлений составило всего 25 случаев по п. 7 ст. 58 и 28 - по п. 14 ст. $58^{22}$.

Приведенные материалы свидетельствуют о существовании прямой зависимости между началом массированной политизации экономических процессов и усилением репрессий, а по сути, террора со стороны государства и проведением политики коллективизации. К таким выводам приходит и О.Б. Мозохин, характеризуя внесудебную деятельность ГПУ - ОГПУ. По его данным, с 1922 по 1934 г. органами госбезопасности были расстреляны 50 тыс. чел. Наибольшее число расстрелов приходится на время осуществления коллективизации, в силу чего можно утверждать, что начало массовых репрессий в стране относится именно к этому периоду ${ }^{23}$. Крестьянская направленность репрессивной практики сохраняется на протяжении всех 1930-х гг. Так, в отчетности 1934 г. (в этом году статистика преступлений по вредительству единственный раз за весь рассматриваемый период была представлена по отраслям народного хозяйства) из 11675 случаев в колхозах и МТС произошло 7115 преступлений, в совхозах - 1775, в промышленности и на транспорте - 2092 24 . К слову, из всех советских граждан, подвергшихся репрессиям в 1937 г., 53 \% составляют крестьяне ${ }^{25}$.

В процессе анализа общей структуры «основных контрреволюционных проявлений» и соответствующих статей УК возникает масса разночтений и вопросов, касающихся четкого определения состава преступлений или, скорее, его отсутствия и возможности произвольного толкования законодательства. Каковы роль и предназначение в процессе тотальной ломки социального организма уникального феномена «вредительство», вобравшего в себя множество смыслов и интерпретаций?

При поиске ответа на этот вопрос весьма продуктивной, на наш взгляд, является концепция английского историка Ника Барона, представившего формировавшуюся административно-командную систему в целом и экономическое планирование в частности в контексте политического дискурса. По мнению исследователя, стратегия сталинского режима, сознательно допускавшего повальные дефициты, узкие места, дисбалансы в распределении ресурсов и систематическое невыполнение плана, состояла в том, чтобы генерировать «зоны неопределенности», порождаемые «исходящими "сверху" несовместимыми сигналами, противоречивыми требованиями и изменчивой двусмысленной фразеологией» 26 . Это, разумеется дестабилизировало ситуацию на местах, внушало страх непосредственным исполнителям, создавало иллюзию ослабления повседневного контроля, 
однако так власть платила за сохранение и укрепление правящего режима. Тем самым мы можем представить концепт «вредительство» как определенную стратегию, «социальный проект», клише, рожденное в недрах пропагандистской машины и предназначенное для генерации «зон неопределенности». Другими словами, власть вольно или невольно создавала условия, неизбежно провоцировавшие исполнителей на нарушение законодательства, а затем маркировала подобные инициативы вредительством и подрывной деятельностью. В этом случае формировалась ситуация заведомой виновности всех исполнителей на местах, а состояние «на крючке» становилось мотивом выполнения решений центра «любой ценой».

Кроме того, советское планирование времен подготовки к индустриальному рывку не просто не отличалось особой последовательностью решений, научной обоснованностью и целесообразностью, но нередко носило хаотичный характер, обусловленный политическим противоборством и конфликтами в высшей партийной элите. Не переставала быть полем битвы и обозначенная «иерархия целей», что не придавало последней стабильности и стимулировало постоянный пересмотр и исправление планов ${ }^{27}$. Отражением внутрипартийной борьбы выступают и заключения органов госбезопасности, выявлявших в действиях республиканских наркоматов земледелия признаки вредительства. Так, в адресованной И. В. Сталину докладной записке ГПУ УССР от 11 января 1930 г. «О вредительстве в сельском хозяйстве» отмечалось, что в ходе агентурно-следственной работы было установлено вредительство по следующим направлениям: в деле стандартизации, районирования и сортосмены; по линии торможения землеустройства и извращения его; а также торможения работ научных и опытных учреждений. Основной задачей вредителей было названо общее замедление всех темпов ${ }^{28}$.

Напомним, что Постановление ЦК ВКП(б) «О темпах коллективизации и мерах помощи колхозному строительству» было обнародовано 5 января 1930 г., а в предшествующее пятилетие официальная позиция советского руководства была полной противоположностью курсу на тотальное огосударствление аграрного сектора экономики. Либерализация аграрных отношений в период НЭПа, нацеленность на товаризацию наиболее крепких хозяйств, столь характерные для середины 1920-х гг., теперь стали серьезным аргументом в пользу обвинения организаторов сельскохозяйственного производства во вредительстве и для вящей убедительности в преступных намерениях и для обоснования участия в следственных действиях органов госбезопасности - в контрреволюционной деятельности. Следуя за текстом докладной записки, отметим, что под ударом ГПУ оказались «старые агрономические деятели», «захватившие командные посты в центральном аппарате Наркомзема УССР и его опытных, научных учреждениях». Трудно не согласиться с мнением спецслужб относительно мировоззренческих ориентиров «спецов», получивших образование в имперской России; подчеркнем при этом расстановку акцентов: востребованная в условиях кадрового голода советского аппарата «буржуазная» интеллигенция в новых условиях уже не вписывалась в новую систему вертикальных связей бюрократической пирамиды. И вот в документах ГПУ появляется «великодержавная» «вредительская контрреволюционная группа кадетско-монархического толка», члены которой дали признательные показания о своих разрушительных действия ${ }^{29}$. Здесь мы имеем дело одновременно и 
с фальсификацией обвинений, и с объективной картиной происходившего, и с вымыслом, и с реальностью. Действительно, с 1923 г. республиканские Наркомземы проводили «совершенно откровенную линию за насаждение отрубов и хуторов», о чем свидетельствует ряд документов, изданных, скажем, Наркомзема УССР в тот период: «Из единоличных форм землепользования наиболее рациональной необходимо признать поселково-отрубную, каковую и следует рекомендовать в случае определенного стремления землепользователей перейти к хуторам и отрубам. Особо следует оценивать хутора и отруба в тех случаях, когда они создаются с целью введения особо интенсивных культур, невозможных в условиях общественного севооборота. Образование такого рода единоличников следует признать безусловно прогрессивным явлением (Бюллетень НКЗ № 23 за 1925 год)»30.

Популяризация передового опыта хуторян привела к возникновению движения крестьян-опытников, или культурников. Организационным центром, координировавшим подобную практику, выступал Опытный отдел Наркомзема РСФСР во главе с А.В. и С. К. Чаяновыми. Культурническое движение к концу 1920-х гг. становится весьма заметным явлением, что вызывает возникновение соответствующих форм отчетности в деятельности губернских земельных управлений.

В качестве примера приведем обращение крестьянина д. Куракино Царевщинской волости Пензенского уезда М. С. Сашенкова в адрес заведующего Пензенским ГЗУ Хабарова с просьбой опубликовать его соображения в региональной печати. Письмо датировано 12 марта 1928 г. и представляет собой пространный экскурс в прошлое, настоящее и будущее русской деревни в представлениях «хуторянина средней руки». Показательно, что Сашенков не скрывает дореволюционный статус своего хозяйства («я хуторянин с 1914 г.»), не маскируется под образ крестьянина-культурника, хотя это достаточно распространенная модель поведения данной эпохи. Более того, он призывает к дальнейшей хуторизации деревни: «допустить обязательно трудовые хутора, но не менее 8-10 десятин на хозяйство», «с разделением на поселки и хутора (призванные стать «светильниками огромным народным массам»), делать всевозможные поощрения: по лесоразведению, защитной полевой посадке и садоводству и т. д.» (сам Сашенков на 11 членов своей семьи имел 20 десятин). Вместе с тем автор крайне критично относится к сохранению общины и насаждению коллективных форм землепользования: «Сам на свете много видел, много странствовал, читал, но, увы, в коммуну русских все же верить я не стал»; «община нас с ленью подружила, уроки косности дала, к раздорам, сварам приучила и гнезда бедности свила»; «коммуны, колхозы и коллективы, поселившиеся когда-то в бывших прекрасных вечных помещичьих постройках, а теперь вследствие небрежного хранения и ремонта пришедших в жалкое положение... владеют прекрасной землей... но страшно задолжавшие и служить примером не могут ${ }^{31}$.

Критика передельной практики присутствует у Сашенкова в одном ряду с характеристикой низового советского аппарата, дискредитировавшего, по его мнению, саму идею народовластия: «С 1905 г. у нас почти ежегодно переделы земли полные и неполные, навозное удобрение совершенно не вносится... хотя сельсоветы и доставляют в Статбюро сведения о вывозке столько-то возов навозу, но это все врут, волостной совет об этом тоже знает и тоже врет, навоз пропадает 
в кучах позади дворов»32. Здесь также присутствует указание на существование еще одной грани противоречий: мы видим разворачивавшийся конфликт между сельской и волостной администрацией и крепкими хозяевами.

В середине 1930 г. ОГПУ проинформировало И. В. Сталина о существовании контрреволюционной и вредительской организации в сельском хозяйстве, политическим центром которой выступало Московское общество сельского хозяйства во главе с Н. Д. Кондратьевым, А. Н. Макаровым, А. В. Чаяновым, А. Н. Челинцевым, А. Г. Дояренко, Д. М. Шорыгиным и др. Как явствовало из показаний Д. М. Шорыгина, в числе «экономических мероприятий, связанных с содействием развитию мощного хозяйства» «крупное место» занимали «опытно-примененческая работа» и формирование института крестьян-опытников ${ }^{33}$. И надо отметить, что до конца 1929 г. деятельность маяков передового опыта, олицетворявших собой либеральную альтернативу административно-командной экономике, ничуть не противоречила лозунгу «Обогащайтесь!». Теперь же, по логике спецслужб, «областные опытные станции и местные опытные поля реально, на практике превратились в центры, хозяйственно укреплявшие десятки тысяч кулаков»34. Очевидно, что появление иделогемы «вредительство» было обусловлено необходимостью переноса борьбы идей и отвлеченных экономических моделей в плоскость реальной практики судебного и внесудебного преследований в отношении носителей ценностей, потенциально чуждых формируемой социокультурной системе.

Следуя принципам герменевтики, производя «археологические» поиски смыслов и связей ${ }^{35}$, отражавших контекст, единство событий и их значений в координатах картины мира соответствующей эпохи, очередную волну репрессий, охватившую советское общество в 1933 г., можно прочесть как официальное признание голода в СССР. Судя по документам ОГПУ, демографическая катастрофа обернулась чудовищными обвинениями в адрес руководства Наркомата земледелия СССР, созданного 7 декабря 1929 г. специально для координации действий республиканских и местных властей по осуществлению коллективизации. В декабре 1932 - январе 1933 г. в центральных союзных структурах (Наркомате земледелия, Наркомате зерновых и животноводческих совхозов, организационно оформившемся только в октябре 1932 г., а также в Трактороцентре СССР) была выявлена контрреволюционная организация, осуществлявшая вредительскую деятельность в сельском хозяйстве. По данным ОГПУ, в состав Политического центра, руководившего контрреволюционной организацией в Трактороцентре, входили М. М. Вольф, Ф.М.Конар (заместитель наркома земледелия) и др. Постоянную связь центра с военным атташе Польского посольства Ковалевским осуществлял М. Е. Коварский (заместитель председателя Трактороцентра): «Согласно договора с Польской миссией к. р. организация получила оружие, которое было направлено в распоряжение периферийных повстанческих ячеек преимущественно в Белоруссии и пограничных районах Украины и распределялось среди участников к. р. организации на селе» ${ }^{36}$. Согласно протоколу показаний М. М. Вольфа, конечной целью политического центра выступали «низвержение Советской власти и создание демократической республики с кулачеством во главе, как основной и руководящей политической силой». Еще более неправдоподобными выглядят планы организации по подготовке «вооруженного восстания [было намечено на весну 1933 г. - В. К., 
О. С.] и проведению по заданиям Политцентра к-р организации вредительской, подрывной и диверсионной работы для ухудшения экономического и политического положения страны, вызова всеобщего недовольства в стране и создания, таким образом, предпосылок для вооруженного восстания»37.

Коллегией ОГПУ, рассмотревшей в судебном заседании от 11 марта 1933 г. дело арестованных «выходцев из буржуазных и помещичьих классов, - государственных служащих в системе Наркомзема и Наркомсовхозов по обвинению их в контрреволюционной вредительской работе в области сельского хозяйства в районах Украины, Северного Кавказа, Белоруссии», 35 наиболее активных участников организации были приговорены к высшей мере социальной защиты, еще столько же получили от 8 до 10 лет тюрьмы ${ }^{38}$.

«Вредителям» инкриминировалась организация контрреволюционного вредительства в машинотракторных станциях и совхозах ряда районов Украины, Северного Кавказа и Белоруссии, нанесшего ущерб крестьянству и государству и выразившегося в порче и уничтожении тракторов и сельскохозяйственных машин, умышленном засорении полей, поджоге машинно-тракторных станций, машинно-тракторных мастерских и льнозаводов, дезорганизации сева, уборки и обмолота с целью подрыва материального положения крестьянства и создания в стране состояния голода ${ }^{39}$.

Еще одним фронтом борьбы с вредителями, отражавшим непоследовательность и поспешность аграрной политики властей, становится практика землеустройства в советской деревне. По мнению известного исследователя сталинской эпохи Ш. Фицпатрик, центральные власти еще в сентябре 1932 г. гарантировали колхозам право на пользование землей, которую они обрабатывают, однако это не остановило произвольные укрупнения и разукрупнения колхозов и земельные переделы по инициативам с мест, что вызывало нарекания ЦК. Но в конце 1935 г. центральная власть поддержала подобную практику, «распорядившись слить "чрезвычайно мелкие" колхозы нечерноземной полосы в более крупные объединения - конечно, “при условии строжайшего соблюдения принципа добровольности"» ${ }^{40}$.

Землемеры и землеустроители, призванные решать проблемы, возникавшие в процессе формирования колхозного земельного фонда, в период коллективизации были во многих отношениях знаковыми фигурами. При этом масштабность задач совершенно не уравновешивалась потребным количеством подготовленных специалистов, что позволяет предположить наличие низкого уровня компетенции у сотрудников земельных отделов и, как следствие, неудовлетворенность крестьянства их работой. По мнению Ш. Фицпатрик, и в середине 1930-х гг. на момент появления закона, закрепившего за колхозами право на вечное пользование землей, в распоряжении местных властей имелась едва ли десятая часть нужного количества работников: в кратчайшие сроки потребовалось более 800 тыс. землеустроителей для оптимизации колхозных земель и решения межевых споров. Утолить в одночасье кадровый голод не удалось, и власти нашли привычный административный метод решения проблемы. Он заключался в организации показательных процессов, в ходе которых землеустроителям инкриминировались вредительские действия, провоцировавшие крестьянское недовольство (неумелое 
перераспределение земельного фонда, преференции совхозам и особенно единоличникам), но по сути специалисты понесли явно несоразмерное наказание за низкую квалификацию и профессионализм ${ }^{41}$.

Проблемы катастрофического падения управляемости народнохозяйственным комплексом, обусловленные во многом форсированным характером индустриализации, спровоцировали новую волну репрессий, подобно цунами захлестнувшую страну в 1937-1938 гг. Провозглашенный И. В. Сталиным лозунг второй пятилетки «Кадры решают все!» стал официальным признанием колоссального разрыва между уровнем технической и интеллектуальной оснащенности советского общества. Введение в строй тысяч новых предприятий, кардинальная перестройка аграрной сферы, системы планирования и т. д. требовали одномоментного вливания в экономику сотен тысяч работников соответствующей квалификации. На подготовку новых специалистов требовались десятилетия. Решить эту проблему в кратчайшие сроки позволяла отработанная в предыдущие годы стратегия кризисного управления, основанная на генерации «зон неопределенности» и переносе ответственности с системы в целом на отдельные ее элементы, маркированные как чуждые и вредоносные, но допустимые как противовес, борьба с которым обеспечивает стабильность последней. Включенность концепта «вредительство» в эту модель очевидна, не случайно отчетность НКВД 1937 г. демонстрирует исторический максимум преступлений по п. 7, 14 ст. 58 УК - 67710 арестованных по обвинению во вредительских действия ${ }^{42}$. Кроме того, топос вредительства как нельзя лучше отражает ситуацию использования мифологем массового сознания в процессе решения задач модернизации: неопределенность, размытость границ предметного содержания с позиций права компенсировалась пониманием греховности, что переводило грандиозный проект создания нового социокультурного пространства в привычные традиционному сознанию координаты.

Состояние сродни массовому психозу, характерное для общественного сознания конца 1937 г., описывает С. Г. Кара-Мурза, опираясь на воспоминания Б. Г. Меньшагина, адвоката, участвовавшего в одном из показательных процессов в Смоленске. Сотрудника московского ВНИИ экспериментальной ветеринарии, проводившего диагностику бруцеллеза в области, обвинили в массовом заражении животных (при инъекции недавно инфицированных животных, не имевших внешних признаков заболевания, действительно возникала определенная реакция, позволявшая поставить точный диагноз) ${ }^{43}$. Вкупе со свидетельскими показаниями доярок, на глазах которых вредители заражали коров и отправляли их на живодерню, вниманию судей были представлены постановления общих собраний колхозников и работников совхозов области с требованием «уничтожить гадов». Суд вынес обвинительный приговор в отношении восьми участников процесса, включая руководителей областного управления животноводства, ветеринаров, секретаря райкома. Всех приговорили к расстрелу ${ }^{44}$.

Трудно согласиться с предположением автора, что в этом случае массовое аномальное состояние было вызвано межфракционными схватками в высшей партийной элите, приведшими к репрессиям почти ритуального свойства, и тиражированием в СМИ абсурдных сценариев охоты на ведьм ${ }^{45}$. Скорее, это можно рассматривать как предложенный властью способ выхода традиционного 
социума из состояния культурного шока, возникшего в результате столкновения с реалиями форсированной индустриализации и сопутствующих процессов, без утраты устойчивости режима в целом. Мощнейшая миграционная активность, разрушение привычного уклада хозяйственной деятельности, угроза разрыва семейных связей - словом, удар по базовым основаниям традиционной картины мира, экстремальный характер повседневности и т. п. послужили предпосылками возникновения предельно критического состояния психики, породили желание возмездия. Вместе с тем сложившаяся ситуация ставила под сомнение осуществление глобального проекта социальной инженерии и требовала вмешательства регулятора.

В этом контексте легитимизация власти в стране и стабилизация социально-политического взаимодействия могла быть обеспечена апелляцией режима к голосу народа: тысячи и тысячи жалоб на действия низового аппарата станут основными доказательствами на процессах Большого террора. На материалах Западной области это убедительно продемонстрировала Ш. Фицпатрик, разбирая жалобы крестьян на деятельность землеустроителей ${ }^{46}$. Многочисленные факты изъятия приусадебных земель в общеколхозный фонд, отвод приусадебных участков вдали от крестьянского двора, изъятие из пользования колхозов лесов и прудов и, соответственно, наложение штрафов за нарушение принятых правил, произвольное изменение границ земель, закрепляемых за колхозами (чересполосица и отрезки земли), завышенные обязательства по мясопоставкам и иные основания для подрыва доверия сельского населения к власти были характерным явлением не только для Западной области, но и для Виницкой и КаменецПодольской областей, что вызвало принятие специального Постановления СНК УССР и ЦК КП(б)У «О ликвидации последствий вредительства в деле колхозного устройства по Винницкой и Каменец-Подольской областям» (утв. ЦК ВКП(б) 5 октября 1937 г. $)^{47}$. По меньшей мере сомнительным представляется тот факт, что «банды национал-фашистов и агентов иностранных фашистских государств, пробравшихся в руководящие земельные и советские органы» ${ }^{48}$ действовали столь согласованно на территории сразу нескольких регионов. Так, 2 августа 1937 г. СНК СССР и ЦК ВКП(б) принимают Постановление «Об оказании помощи колхозному крестьянству Белорусской ССР и о ликвидации последствий вредительства в деле колхозного устройства» аналогичного содержания ${ }^{49}$. Вероятно, ранее подобная практика особых нареканий не вызывала, если не была негласно санкционирована руководством страны, - не случайно ответственность за ликвидацию последствий вредительства была возложена на Винницкий обком, облисполком и Оргбюро КП(б)У по Каменец-Подольской области, которые вряд ли находились в неведении о незаконном изъятии приусадебных земель у колхозников и зачислении таковой в общеколхозный фонд 50 .

Документы, выявленные в ходе проведенного исследования, свидетельствуют о формировании определенного типового протокола для информационной поддержки подобных процессов. Так, согласно шифровке и. о. секретаря Западного обкома ВКП(б) Коротченкова, адресованной И. В. Сталину, 24 августа 1937 г. спецколлегия облсуда на своей выездной сессии начала слушание дела о «контрреволюционной банде вредителей, орудовавшей в сельском хозяйстве Андреевского 
района»: «Интерес к процессу большой. В зале суда присутствует свыше 500 чел. колхозников из всех сельсоветов и колхозов района. 24 августа во всех сельсоветах района и большинстве колхозов проведены митинги, собрания и читки материалов о процессе. Ежедневно выпускается газета многотиражка. Для массовой работы в сельсоветы и колхозы направлен районный актив. В колхозах выделены чтецы и беседчики о процессе. Поступает много резолюций от трудящихся районов с требованием применения к вредителям высшей меры наказания, колхозники берут конкретные обязательства - повышение революционной бдительности, досрочная сдача хлебозаготовок и госпоставок, быстрейшее окончание озимого сева, обработки льна, усиление подписки на заем и т. д. „51 Показательна ответная реляция Сталина на поступившую информацию: «Советую приговорить вредителей Андреевского района к расстрелу, а о расстреле опубликовать в местной печати»52.

В конце лета - осенью 1937 г. волна процессов над вредителями прокатилась по всей стране. Так, 24-28 августа в Грузии состоялся процесс над «контрреволюционной, террористической, диверсионно-вредительской организацией правых Сигнахского района»53. Среди обвиняемых - бывший секретарь Сигнахского РК КП(б) Грузии А. Б. Цитлидзе, председатель РИКа Ш. Б. Алавердашвили, директор МТС И. Б. Степанов, директор Эльдарского овцеводческого совхоза К. И. Абашидзе и др., всего 11 чел.

Зал районного театра, в котором проходил процесс, был переполнен представителями колхозов, совхозов, МТС и других организаций Сигнахского района. Около 6000 крестьян, которым не хватило места в зале, следили за происходившем по радиотрансляции, заполнив площадь перед театром. Процесс транслировался по радио- и телефонной сети во все сельсоветы района. Как отмечалось в телефонограмме секретаря ЦК КП(б) Грузии Л.П. Берии, «все обвиняемые полностью признали себя виновными в предъявленных им обвинениях и в своих показаниях дополнили установленную на предварительном следствии картину рядом новых подробностей своей гнусной предательской, диверсионно-вредительской контрреволюционной работы „54. Повсеместно в районе на митингах колхозников, рабочих совхозов и МТС вынесены решения с требованиями расстрела обвиняемых и обещаниями ликвидировать до конца последствия вредительства. Подобных примеров можно привести множество. Страну захлестнула истерия охоты на ведьм.

Не стоит сбрасывать со счетов и тот факт, что низовой слой этакратии был плоть от плоти своего народа: наследие традиционной ментальности позволило С.Г. Кара-Мурзе назвать движущей силой тоталитаризма массовую страстную волю «выполнить признанную необходимой задачу, не считаясь ни с какими жертвами» (советский энтузиазм, по сути, стал оборотной стороной религиозного фанатизма). По словам исследователя, центральной власти приходилось даже сдерживать необоснованное рвение местных не в пример царскому или Временному правительству, потерпевшему фиаско именно по причине резкого падения исполнительской дисциплины ${ }^{55}$. В целях регуляции подобных настроений ЦИК СССР 25 июня 1932 г. принимает специальное Постановление «О революционной законности», ограничивавшее местную инициативу внесудебных действий ${ }^{56}$.

В дальнейшем произвол рядовых исполнителей партийных директив послужил основанием для организации истребления целого слоя номенклатуры, на который 
была возложена непопулярная миссия слома прежней системы. Объективно их судьба была предрешена с самого начала, и под катком репрессий оказалось все высшее управленческое звено районного уровня. На процессах Большого террора среди обвиняемых будут фигурировать, как правило, секретари райкомов и председатели райисполкомов, директора МТС, заведующие земельными отделами и отделами животноводства ${ }^{57}$. Столь высокая активность по выявлению и осуждению вредителей в сельском хозяйстве в стране на ограниченном отрезке времени (конец августа - сентябрь 1937 г.) свидетельствует об организованном характере кампании, запущенной ЦК в директивном порядке. Ожидаемым в этом случае будет и рвение региональных властей, оказавшихся заложниками ситуации. Беспощадная борьба с вредительством позволяла реабилитироваться перед центром за провал коллективизации. В подтверждение этого приведем текст шифровки, поступившей на имя И. В. Сталина и Н. И. Ежова 22 августа 1937 г. из Ростова-на-Дону: «Во исполнение директивы ЦК о проведении открытых процессов по имевшим место массовым отравлениям в крае проведены 3 процесса - в Новороссийске, Красном Сулине и Приморско-Ахтарской. 5 обвиняемых приговорены к расстрелу, остальные к лишению свободы на 10 лет. Подготавливаются к слушанию еще дела»58. Аналогичные сообщения поступили в ЦК в последней декаде августа из Курска (борьба с вредительством здесь началась после получения телеграммы из ЦК ВКП(б) от 4 июля 1937 г. о проведении открытых показательных процессов над вредителями в сельском хозяйстве ${ }^{59}$ ), Харькова ${ }^{60}$, Винницы (указание ЦК поступило 3 августа $\left.{ }^{61}\right)$, Воронежа ${ }^{62}$ и других региональных центров.

Помимо информации об организации процессов и их результатах выявленные источники позволяют осуществить классификацию штатных обвинений в адрес «троцкистско-бухаринских контрреволюционных банд» ${ }^{63}$. После освобождения от идеологизированных клише («троцкистско-бухаринские бандиты, шпионы, вредители, диверсанты» и пр.) становятся очевидными наиболее проблемные места системы властно-политического регулирования в аграрной сфере. В частности, партийные функционеры Западно-сибирского крайкома ВКП(б) к сфере вредительства отнесли следующее: умышленное заражение скота инфекционными болезнями и, как следствие, массовый падеж животных; преднамеренное противодействие планам сева и обработке технических культур; затягивание процесса закрепления земли в вечное пользование за колхозами и мероприятий по введению на полях колхозов правильных севооборотов; массовое незаконное наложение штрафов и арестов текущих счетов колхозов; взыскание с населения незаконных поборов в виде налога с печей - «дымналог», налога с собак - «собаконалог», налога с заготовляемого сена - «сеноналог»; отчуждение за недоимки жилищ колхозников; срыв подготовки складских помещений к приемке хлеба на пунктах «Заготзерно»; намеренное заражение хлеба клещом; смешивание зерна равных культур, сортового с рядовым; выделение колхозам на семена заведомо недоброкачественного зерна ${ }^{64}$. Налицо ощутимый разрыв между стратегией модернизации сельского хозяйства и демографическими, хозяйственными и социокультурными ресурсами советской деревни в период осуществления реконструкции. В этом случае топос вредительства измеряется: низким уровнем санитарно-гигиенической 
культуры; условиями содержания скота в коллективных хозяйствах; отсутствием необходимого количества квалифицированных специалистов для профилактики заболеваний животных (это способствовало распространению эпидемий крупного рогатого скота в колхозах страны); низким уровнем знаний и нехваткой специалистов в сфере агрономии и землеустройства; отсутствием современной инфраструктуры для хранения и очистки зерна; явной несоразмерностью плановых заданий возможностям созданных наспех колхозов, вынуждавшей управленцев идти на всяческие ухищрения ради выполнения партийных заданий, - по сути, для решения задач модернизации применялись методы феодальной эпохи (внеэкономического принуждения).

Таким образом, изучение концепта «вредительство» имеет большую познавательную ценность, что позволяет разрешить ряд противоречий методологического и источниковедческого характера. Это понятие является ключевым для понимания сущности эпохи, отражением родовых признаков глобального проекта социальной перестройки, охватившего советское общество в конце 1920-х - 1930-е гг. Предназначением этого проекта выступало формирование определенного смыслового социокультурного пространства, призванного компенсировать заведомые социальные издержки и жертвы и необходимого для восстановления равновесия системы социально-политического взаимодействия. Апелляция к нормам обычного права, к правовым представлениям, характерным для общественного сознания домодерновой эпохи, была необходима как для оптимальной регуляции социального поведения, позволявшей направлять массовое недовольство в безопасное для государства русло, так и для исправления погрешностей оперативного управления и укрепления исполнительской дисциплины в условиях форсированной индустриализации. Однако тактические выгоды, полученные на фронтах борьбы с вредительством, совершенно не уравновешивались жертвами, принесенными на алтарь модернизации, что доказывает историческую несостоятельность и самого понятия, и управленческой стратегии, его создавшей.

1 Статья подготовлена при финансовой поддержке РГНФ в рамках проекта «Политбюро ЦК ВКП(б) и проблема вредительства в сельском хозяйстве СССР в 1930-1940-е гг. по документам Архива Президента РФ и региональных архивов» № 15-01-00143.

2 Тоталитарные методы борьбы с тоталитарным наследием: материалы экспертного опроса // Журнал российских и восточноевропейских исследований. 2011. № 1(3). С. $17-47$.

3 Предложения об учреждении общенациональной государственно-общественной программы «Об увековечении памяти жертв тоталитарного режима и о национальном примирении» // Журнал российских и восточноевропейских исследований. 2011. № 1(3). С. 4.

4 Левин М. Советский век / пер. с англ. В. Новикова, Н. Копелянской. М., 2008. С. 17-18.

5 Там же. С. 594.

6 Захарченко Г.В. Социально-политическая природа массовых репрессий в СССР // Ведомости уголовно-исполнительной системы. 2012. № 6. С.33. URL: http://elibrary.ru/item. asp?id=18861198 (дата обращения: 10.07.2016).

7 Ясперс К. Истоки истории и ее цель // Ясперс К. Смысл и назначение истории / пер. с нем. М., 1991. С. 142.

8 Там же. С. 148. 
9 Там же. С. 149.

10 Боровкова О.В. Исторический источник и внеисточниковое знание в исторической науке // Вестник Томского государственного университета. 2015. № 390. C. 39. URL: http://elibrary. ru/item.asp?id=23142957 (дата обращения: 10.07.2016).

11 Там же. С. 41-42.

12 Гуревич А.Я. О кризисе современной исторической науки // Вопросы истории. 1991. № 2-3. C. 26-28, 34-35.

13 Лившин А.Я., Орлов И. Б. Власть и общество: диалог в письмах. М., 2002. С. 12, 23.

14 Арнаутов И.Б. Образ «вредителя» в газете «Правда» (декабрь 1934 - декабрь 1938 г.) // Вестник НГУ. Сер. История, фрилология. 2010. Т.9, вып. 1. История. С. 292-293. URL: http:// elibrary.ru/item.asp?id=13026975 (дата обращения: 10.07.2016).

15 Уголовный кодекс РСФСР редакции 1926 г. (с изменениями по состоянию на 1 марта 1957 г.). M., 1957. URL: http://docs.cntd.ru/document/901757374 (дата обращения: 15.11.2015).

16 Мозохин О.Б. Право на репрессии. Внесудебные полномочия органов государственной безопасности. М., 2011.

17 Статистические сведения о деятельности органов ВЧК - ОГПУ - НКВД - МГБ // Там же. С. 334-626.

18 Там же. С. 364, 383.

19 Там же. С. $383,397$.

20 Там же. С. 397-469.

21 Там же. С. 454.

22 Там же. С. 620-621.

23 Там же. С. 126.

24 Там же. С. 436.

25 Там же. С. 461.

26 Барон Н. Экономическое планирование и государственное насилие накануне Большого террора, 1935-36 гг. // Советская власть - народная власть? Очерки народного восприятия советской власти в СССР / под ред. Т. Вихавайнена. СПб., 2003. С. 202-203.

27 Там же. С. 204.

28 Архив Президента Российской Федерации (далее - АП РФ). Ф. 3. Оп. 40. Д. 380. Л. 8.

29 Там же. Л. 3.

30 Там же. Л. 10.

31 Государственный архив Пензенской области (далее - ГАПО). Ф. p-309. Оп. 1. Д. 3683. Л. 244.

32 ГАПО. Ф.р-309. Оп. 1. Д. 3683. Л. 244.

33 АП РФ. Ф. З. Оп. 40. Д. 380. Л. 82, 88.

34 Там же. Л. 88.

35 Кара-Мурза С. Г. Манипуляция сознанием. М., 2002. С. 23, 27.

36 АП РФ.Ф. 3. Оп. 40. Д. 385. Л. 32.

37 Там же. Л. 33.

38 Там же. Л. 136.

39 Там же.

40 Фицпатрик Ш. Сталинские крестьяне. Социальная история Советской России в 30 -е годы: деревня / пер. с англ. Л. Ю. Пантина. М., 2008. С. 126.

41 Там же. С. 126-127.

42 Статистические сведения о деятельности органов ВЧК - ОГПУ - НКВД - МГБ. C. 460 .

43 Кара-Мурза С. Г. Советская цивилизация. Кн. 1. От начала до Великой Победы. М., 2002. C. 512.

44 Там же.

45 Там же.

46 Фицпатрик Ш. Сталинские крестьяне... С. 127.

${ }_{47}$ АП РФ. Ф. 3. Оп. 40. Д. 389. Л. 17-20.

48 Там же. Л. 18. 
49 Там же. Д. 387. Л. 137-141.

50 Там же. Д. 389. Л. 18.

51 Там же. Д. 388. Л. 4

52 Там же. Л. 5.

53 Там же. Л. 12.

54 Там же.

55 Кара-Мурза С. Г. Советская цивилизация. Кн. 1. С. 478.

56 Постановление Центрального Исполнительного Комитета и Совета Народных Комиссаров CCCP от 25 июня 1932 г. «О революционной законности». URL: www.gumer.info/bibliotek_ Buks/History/Article/rev_zakon.php (дата обращения: 25.07.2016).

${ }^{57}$ АП РФ. Ф. 3. Оп. 40. Д. 387.

58 Там же. Л. 162.

59 Там же. Л. 165.

60 Там же. Л. 167.

61 Там же. Л. 169.

62 Там же. Л. 171.

63 Там же. Д. 389. Л. 2.

64 Там же. Л. 2-6.

\section{ДЛЯ ЦИТИРОВАНИЯ}

Кондрашин В.В., Сухова О.А. Феномен вредительства в социально-политическом контексте и современном дискурсе гуманитарного знания // Новейшая история России. 2017. № 2 (19). С. 144-161. УДК 947.084 .5

Аннотация: На основе изучения документов Архива Президента Российской Федерации и региональных архивов авторы приходят к выводу о ключевом значении концепта «вредительство» для понимания сущности эпохи в контексте отражения масштабнейшего социального проекта, охватившего советское общество в конце 1920-х - 1930-е гг. Предназначением этого проекта выступало формирование определенного смыслового социокультурного пространства, призванного компенсировать заведомые социальные издержки и жертвы и необходимого для восстановления равновесия системы социально-политического взаимодействия. Апелляция к нормам обычного права, к правовым представлениям, характерным для общественного сознания домодерновой эпохи, была необходима как для оптимальной регуляции социального поведения, позволявшей направлять массовое недовольство в безопасное для государства русло, так и для исправления погрешностей оперативного управления и укрепления исполнительской дисциплины в условиях форсированной индустриализации. Приведенные материалы свидетельствуют о существовании прямой зависимости между началом массированной политизации экономических процессов и усилением репрессий, а по сути, террора со стороны государства, и проведением политики коллективизации. «Вредителям» инкриминировалась организация контрреволюционного вредительства в машинно-тракторных станциях и совхозах ряда районов Украины, Северного Кавказа и Белоруссии, нанесшего ущерб крестьянству и государству и выразившегося в порче и уничтожении тракторов и сельскохозяйственных машин, умышленном засорении полей, поджоге машинно-тракторных станций, машинно-тракторных мастерских и льнозаводов, дезорганизации сева, уборки и обмолота с целью подрыва материального положения крестьянства и создания в стране состояния голода и пр. В дальнейшем произвол рядовых исполнителей партийных директив послужил основанием для организации истребления целого слоя номенклатуры, на который была возложена непопулярная миссия слома прежней системы. Объективно их судьба была предрешена с самого начала, и под катком репрессий оказалось все высшее управленческое звено районного уровня. На процессах Большого террора среди обвиняемых будут фигурировать, как правило, секретари райкомов и председатели райсполкомов, директора МТС, заведующие земельными отделами и отделами животноводства. 
Ключевые слова: СССР, сталинская модернизация, Уголовный кодекс РСФСР 1926 г., репрессии, вредительство, сельское хозяйство, крестьянство.

Сведения об авторах: Кондрашин В.В. - доктор исторических наук, профессор, заведующий кафедрой «История России, краеведение и методика преподавания истории», Пензенский государственный университет (Пенза, Россия); vikont37@yandex.ru | Сухова О.А. - доктор исторических наук, профессор, декан историко-филологического факультета, Пензенский государственный университет (Пенза, Россия); suhhov747@yandex.ru

\section{FOR CITATION}

Kondrashin V. V., Sukhova O. A. The Phenomenon of Sabotage in the Socio-Political Context and in Contemporary Discourse of Humanitarian Knowledge, Modern History of Russia, no. 2, 2017. P. $144-161$.

Abstract: On the basis of the documents of the Archive of the Russian Federation President and regional archives authors come to a conclusion about the key importance of "sabotage" of the concept for the understanding of the era, in the context of large-scale reflection of the social project that engulfed Soviet society in the 1920 s - 1930s. Its purpose advocated the formation of a meaning of social and cultural space, necessary to compensate for the social cost and sacrifice and for the rebalancing of the system of social and political interaction. The appeal to customary law, to a picture of the world of the traditional society, was needed for optimal regulation of social behavior and strengthening executive discipline in the conditions of forced industrialization. These documents indicate the existence of a direct relationship between the start of a massive politicization of economic processes and increased repression and the policy of collectivization. "Saboteurs" were punished for the organization of counter-revolutionary sabotage in the machine-tractor stations and state farms of a number of areas of Ukraine, the North Caucasus and Belarus, expressed in the deterioration and destruction of tractors and agricultural machinery, deliberate contamination of fields, setting fire machine-tractor stations, machine-tractor workshops harvesting and threshing in order to undermine the material situation of the peasantry and the creation of the state of hunger in the country and so forth. In the future, the arbitrariness of ordinary executors of party guidelines served as the basis for the organization of the extermination of an entire layer of the nomenclature, which was entrusted with the mission of breaking the unpopular former system. Objectively, their fate was sealed from the outset, and all top managers at the district level have been punished. In the process of the Great Terror among the accused will appear, as a rule, the secretaries and chairmen of district committees, MTS director, heads of departments of land and livestock departments.

Keywords: USSR, Stalin's modernization, RSFSR Criminal Code of 1926, repression, sabotage, agriculture, peasantry.

Authors: Kondrashin V. V. - Doctor of History, Professor, Head of department "History of Russia, regional studies and methodology of teaching history", Penza State University (Penza, Russia); vikont37@yandex.ru | Sukhova O. A. - Doctor of History, Professor, Dean of the Faculty of History, Literature and Philology, Penza State University (Penza, Russia); suhhov747@yandex.ru

\section{References:}

Arnautov I. B. 'Obraz "vreditelya" v gazete "Pravda" (dekabr' 1934 - dekabr' 1938 goda)', Vestnik NGU. Ser.: Istoriya, filologiya, vol. 9, no. 1, 2010.

Baron N. 'Ekonomicheskoe planirovanie i gosudarstvennoe nasilie nakanune Bolshogo terrora, 1935-36 gg.', Sovetskaya vlast - narodnaya vlast? Ocherki narodnogo vospriyatiya sovetskoj vlasti v SSSR. Ed. T. Vihavainen (St. Petersburg, 2003).

Borovkova O.V. 'Istoricheskiy istochnik i vneistochnikovoe znanie v istoricheskoj nauke', Vestnik Tomskogo gosudarstvennogo universiteta, no. 390, 2015.

Fitzpatrick S. Stalinskie krestyane. Sotsialnaya istoriya Sovetskoy Rossii v 30-e gody: derevnya. Transl. L. Yy. Pantin (Moscow, 2008).

Gurevich A. Ya. 'O krizise sovremennoj istoricheskoy nauki', Voprosy istorii, no. 2-3, 1991. 
Jaspers K. 'Istoki istorii i ee tsel' Jaspers K. Smysl i naznachenie istorii (Moscow, 1991).

Kara-Murza S. G. Manipulyatsiya soznaniem (Moscow, 2002).

Kara-Murza S. G. Sovetskaya civilizaiya. Ot nachala do Velikoy Pobedy (Moscow, 2002).

Lewin M. Sovetskiy vek. Transl. V. Novikov, N. Kopelyanskaya (Moscow, 2008).

Livshin A. Ya., Orlov I. B. Vlast i obshchestvo: dialog v pismakh (Moscow, 2002).

Mozokhin O.B. Pravo na repressii. Vnesudebnye polnomochiya organov gosudarstvennoy bezopasnosti. (Moscow, 2011).

'Predlozheniya ob uchrezhdenii obshchenatsionalnoy gosudarstvenno-obshchestvennoy programmy "Ob uvekovechivanii pamyati zhertv totalitarnogo rezhima i o natsionalnom primirenii"', Zhurnal rossiyskih i vostochnoevropejskih issledovaniy, no. 1 (3), 2011.

'Totalitarnye metody borby s totalitarnym naslediem: materialy ekspertnogo oprosa', Zhurnal rossiyskikh i vostochnoevropeyskikh issledovaniy, no. 1 (3), 2011.

Zakharchenko G.V. 'Socialno-politicheskaya priroda massovykh repressiy v SSSR', Vedomosti ugolovnoispolnitelnoy sistemy, no. 6, 2012. 